DOI: $\underline{\text { https://doi.org/10.31933/jemsi.v3i3 }}$

Received: 10 November 2021, Revised: 20 Desember 2021, Publish: 1 Januari 2022

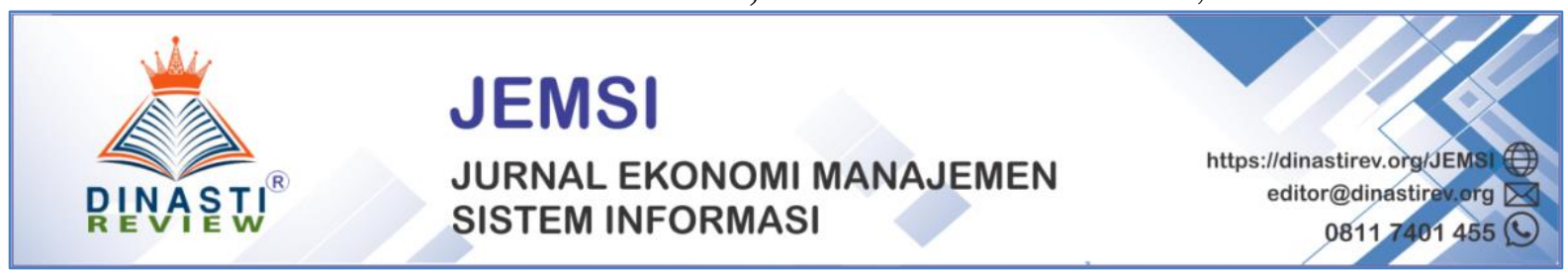

\title{
FAKTOR-FAKTOR YANG MEMPENGARUHI KEPEMIMPINA: KUALITAS KERJA, EFEKTIVITAS KERJA, DAN KOMUNIKASI KERJA (LITERATURE REVIEW KUALITAS KERJA)
}

\author{
Heru Tian Sanjaya', Muhammad Rafli hermawan², Bima Dwi Mardika ${ }^{3}$ \\ ${ }^{1}$ Mahasiswa Fakultas Ekonomi, Universitas Bhayangkara Jakarta Raya, \\ Email: herutian10@gmail.com \\ ${ }^{2}$ Mahasiswa Fakultas Ekonomi, Universitas Bhayangkara Jakarta Raya, \\ Email: muhammad.rafli2801@gmail.com \\ ${ }^{3}$ Mahasiswa Fakultas Ekonomi, Universitas Bhayangkara Jakarta Raya, \\ Email: bimamardika@gmail.com
}

Korespondensi Penulis: Heru Tian Sanjaya ${ }^{1}$

\begin{abstract}
Abstrak: Salah satu faktor terpenting dalam pencapaian suatu perusahaan adalah semua pihak,baik itu pegawai, buruh, karyawan ataupun pekerja terutama seorang pemimpin di perusahaan tersebut yang memiliki peran penting dalam memantau Kinerja para pegawai di Perusahaan itu, karena seorang pemimpin bisa dikatakan sebagai ujung tombak dalam suatu perusahaan tersebut yang artinya seorang pemimpin akan memiliki pengaruh yang besar atas kemajuan dan juga perkembangan di perusahaan itu, tetapi dimana masih banyaknya pegawai yang menyelesaikan pekerjaannya secara tidak konsisten atau bisa di sebut asal jadi, dan juga rendahnya penyesuaian diri terhadap lingkungan kerja seperti penyerahan hasil pekerjaan yang tidak tepat waktu, rendahnya inisiatif pegawai dalam bekerja melakukan kelalaian dalam menjalankan tugas pekerjaan yang di berikan yang mana dalam hal ini seorang pemimpin dalam ruang lingkup pekerjaan itu harus selalu bersikap tegas (firm attitude) dan harus selalu memberikan arahan juga memantau perkembangan pekerjaan para karyawannya, dan seorang pemimpin juga harus selalu menjaga komunikasi yang baik (good communication) terhadap semua karyawan. Tujuan penulisan artikel ini guna membangun hipotesis pengaruh antar variabel untuk digunakan pada riset selanjutnya.
\end{abstract}

Kata Kunci: Kualitas kerja, Efektivitas kerja dan Komunikasi kerja

\section{PENDAHULUAN}

\section{Latar Belakang Masalah.}

Kepemimpinan sebagai konsep manajemen di dalam organisasi memiliki kedudukan yang strategis dan merupakan ciri sosial yang diperlukan dalam kehidupan berorganisasi. Mempunyai kedudukan strategis karena kepemimpinan merupakan titik tengah dan penggerak seluruh proses kegiatan organisasi. Sehingga kepemimpinan mempunyai peran utama dalam menentukan bergeraknya kegiatan dari sumber yang ada. Disamping 
kedudukannya yang strategis, kepemimpinan sangat diperlukan, dimana terjadi interaksi kerja sama antara dua orang atau lebih dalam mencapai tujuan organisasi, Kepemimpinan juga bisa di katakan sebagai kemampuan untuk mempengaruhi sebuah organisasi dan mengarahkannya pada tujuan bersama. Kepemimpinan mampu membawa peran penting dalam organisasi, sehingga tujuan organisasi dapat dicapai dengan baik dan terarah.

Kinerja karyawan memiliki hubungan dengan gaya kepemimpinan yang diterapkan oleh pemimpin. Pengaruh dari seorang pemimpin sangatlah menentukan, karena untuk mencapai tujuan, organisasi harus menterapkan gaya kepemimpinan atau pola kerja yang konsisten terhadap situasi kerja yang dihadapi. Gaya kepemimpinan yang sesuai dan mampu menciptakan kondisi kerja yang nyaman dan baik dapat memberikan semangat kepada karyawan untuk bekerja lebih baik. Dengan demikian karyawan akan bekerja dengan nyaman dan maksimal karena memiliki pemimpin yang baik, sehingga kinerja karyawan akan menjadi lebih baik.

Artikel ini membahas tentang kualitas kerja, efektivitas karyawan dalam bekerja dan komunikasi dalam ruang lingkup kerja, suatu studi literatur faktor-faktor yang mempengaruhi kepemimpinan.

\section{Rumusan Masalah}

Berdasarkan latar belakang, maka dapat di rumuskan permasalahan yang akan dibahas guna membangun hipotesis untuk riset selanjutnya yaitu:

1) Apakah Kualitas Kerja berpengaruh terhadap kepemimpinan?

2) Apakah Efektivitas Kerja berpengaruh terhadap kepemimpinan?

3) Apakah Komunikasi Kerja berpengaruh terhadap kepemimpinan?

\section{KAJIAN TEORI}

\section{Kepemimpinan}

Kepemimpinan dalam organisasi juga menuntut kepekaan terhadap budaya yang terdapat dalam organisasi. Budaya dalam organisasi ini mempunyai fungsi antara lain: menetapkan batas dan wewenang, memberikan rasa identitas kepada anggotanya. Karakteristik budaya dalam organisasi dapat dijadikan pedoman bagi pimpinan untuk membuat keputusan agar organisasi lebih efektif dalam mencapai tujuan. (Burhanudin, 2018)

Siagian (2002) mengemukakan bahwa Kepemimpinan adalah individu yang menduduki suatu jabatan tertentu dimana individu ini memiliki kemampuan dan keterampilan untuk mempengaruhi perilaku orang lain yakni bawahannya untuk berfikir dan bertindak sehingga melalui perilaku yang positif tersebut dapat memberikan kontribusi dalam pencapaian tujuan organisasi. (Burhanudin, 2018)

Kepemimpinan sampai saat ini dianggap sebagai faktor yang sangat penting dalam sebuah organisasi. Kepemimpinan dalam hal ini bisa disebut juga sebagai proses mempengaruhi orang lain dalam suatu komunitas yang diarahkan demi tercapainya suatu 
tujuan bersama. Pemimpin sebagai pihak yang menentukan bagaimana perintah itu dilaksanakan agar keputusan dapat dilakukan secara efektif. (Hasan, 2017)

Kepemimpinan yang efektif memerlukan kompetensi atau kemampuan untuk menggerakkan dan memotivasi orang lain agar mau melaksanakan sesuatu yang diinginkan oleh seorang pemimpin. Kepemimpinan dalam organisasi mempunyai peran yang sangat besar dalam membangun hubungan antar individu dan pembentuk nilai organisasi yang dijadikan sebagai pedoman yang sangat mendasar untuk pencapaian suatu tujuan. Pengaruh kepemimpinan terhadap efektivitas organisasi dapat dilihat sebagai efek kepemimpinan secara langsung dan tidak langsung. (Hasan, 2017). Kepemimpinan sudah banyak di teliti oleh peneliti sebelumnya diantaranya adalah: (Limakrisna et al., 2016), (Bastari et al., 2020), (Anwar et al., 2020), (Ali et al., 2016), (Djoko Setyo Widodo, P. Eddy Sanusi Silitonga, 2017), (Chauhan et al., 2019), (Elmi et al., 2016).

\section{Kualitas Kerja}

Bagaimana cara mempertahankan manusia dalam suatu organisasi dengan baik? kualitas kerja adalah isu penting untuk menjawab pertanyaan itu. Kualitas kerja yaitu cara yang baik dalam perihal menarik dan mempertahankan karyawan supaya memperoleh kinerja yang lebih baik (Salmani, 2005; Farjad, 2013). Kualitas kerja adalah topik yang sangat penting dalam manajemen sumber daya manusia dalam pembangunan organisasi selain masalah etika dan kepuasan kerja beberapa tahun belakangan ini (Moghimi, Kazemi \& Samiie, 2012). (Arrafiqur, 2017)

Kualitas kerja sekarang dipandang sebagai dimensi penting dari kualitas hidup. Kualitas kerja yang tinggi sangat penting bagi organisasi untuk menarik dan mempertahankan karyawan (Boonrod, 2009; Kanten \& Sadullah, 2012). Ketika organisasi memberikan kualitas kehidupan kerja kepada karyawan mereka, itu bisa di sebut sebagai pertanda yang baik untuk meningkatkan imej dalam menarik dan mempertahankan karyawanya. Dalam hal ini perusahaan dapat menawarkan lingkungan kerja yang sesuai kepada karyawan dan pada akhirnya karyawan akan mempunyai komitmen yang sangat tinggi dan organisasi dapat pula mengurangi jumlah biaya karena adanya suatu tekanan yang cukup tinggi (Sarina Muhamad Noor \& Mohamad Adli Abdullah, 201. (Arrafiqur, 2017)

Mangkunegara (2010) berpendapat kinerja adalah hasil kerja secara kualitas dan kuantitas yang dicapai oleh karyawan dalam melakukan tugasnya sesuai dengan tanggung jawab yang diberikan kepadanya. Jika karyawan memiliki kepuasan kerja yang tinggi, maka secara langsung karyawan akan loyal terhadap perusahaan dan kinerjanya juga pasti akan semakin meningkat (Astrianditya, 2016)

Karyawan adalah aset yang berharga yang dimiliki suatu perusahaan, berhasilnya suatu produk di pasaran dapat diilihat dari kualitas perusahaan. Kinerja karyawan menjadi bagian terpenting untuk kemajuan perusahaan di samping strategi dan produk yang inovatif. Kinerja yang baik akan dipengaruhi oleh kepuasan kerja yang akan di dapatkan oleh 
perusahaan tersebut. Dengan kata lain, perusahaan yang berkualitas yaitu perusahaan yang memiliki kualitas hidup kerja yang sangat baik, bisa mensejahterakan karyawan sehingga menghasilkan karyawan yang berkualitas dan berkompetensi tinggi. (Astrianditya, 2016) Kualitas kerja sudah banyak di teliti oleh peneliti sebelumnya diantaranya adalah: (Elmi \& Ali, 2017), (Agussalim et al., 2016), and (Prayetno \& Ali, 2020), (Ansori \& Ali, 2017).

\section{Efektivitas Kerja}

Terjadinya perubahan-perubahan dalam suatu perusahaan juga mempunyai dampak pada perubahan dalam tugas serta kewajiban para pegawai. Semua pegawai diharapkan menjadi lebih kreatif untuk mencari cara baru agar bisa memperbaiki efektivitas dan efisiensi kerja di suatu perusahaan. Ketika perusahaan mengurangi jumlah pegawai, perusahaan itu akan lebih bergantung pada kinerja para pegawai yang masih ada untuk melakukan suatu hal melebihi apa yang ditugaskan kepada mereka. (Azzahra, 2011)

Efektivitas adalah suatu konsep yang sangat amat penting dalam suatu perusahaan, karena bisa memberikan gambaran mengenai keberhasilan perusahaan dalam tujuannya, yang berhubungan dengan jawaban atas pertanyaan "sejauh mana suatu hal yang telah direncanakan untuk bisa meraih tujuan yang akan dicapai”. Secara umum, kefeektifan bisa dihubungkan dengan pencapaian sasaran yang telah ditentukan ataupun dibandingkan dengan hasil nyata dengan hasil yang ideal. Keefektifan lebih merujuk kepada hasil evaluasi terhadap proses yang akan menghasilkan suatu keluaran yang dapat diamati. (Nur, 2012)

Efektivitas kerja ialah penyelesaian pekerjaan tepat waktu yang telah ditentukan artinya apakah pelaksanaan tugas tersebut dinilai cukup baik atau tidaknya bergantung pada bagaimana tugas itu dilaksanakan, terutama tidak menjawab bagaimana cara melaksanakannya, berapa biaya dikeluarkan itu. (Siagian, 1997:151). (Reza, 2019)

Handoko menyebutkan bahwa variabel-variabel yang sangat berpengaruh terhadap efektivitas kerja adalah: komunikasi, lingkungankerja, kepemimpinan, motivasi, kebijakan dan praktek manajemen (Zuliyanti, 2005). (Reza, 2019), (Harini et al., 2020), (Silitonga et al., 2017), and (Masydzulhak et al., 2016).

\section{Komunikasi Kerja}

Selain kepemimpinan, komunikasi merupakan hal yang penting terhadap efektivitas kerja. Karena perintah atau kebijakan pimpinan apapun jika tidak dikomunikasikan terlebih dahulu dengan baik maka akan berdampak negatif terhadap efektivitas kerja pegawai.(Wilson, 2012) menyatakan bahwa komunikasi merupakan sarana yang penting untuk menyampaikan dan menerima informasi kepada atau dari pihak lainnya. (Reza, 2019)

Bagi suatu organisasi meningkatkan semangat kerja pegawai adalah unsur yang sangat penting karena akan mempengaruhi prestasi suatu perusahaan, oleh karena itu dengan semangat kerja diharapkan semua aturan ditaati oleh seluruh pegawai selain itu juga dengan 
semangat kerja akan memperoleh banyak keuntungan yang akan di dapat dan di rasakan. pencapaian tujuan organisasi akan tercapai dengan cara yang efektif dan efisien seperti pekerjaan akan lebih cepat diselesaikan, kerusakan akan cepat di atasi, absensi dapat diperkecil dan produktivitas kerja akan semakin meningkat. (Mardani, 2013)

Komunikasi dalam perusahaan bisa dikatakan sebagai penentu keberhasilan dalam Pencapaian tujuan, dengan komunikasi akan terjadi hubungan timbal balik dari tiap-tiap orang dalam perusahaan tersebut baik berupa perintah, saran, pendapat maupun kritik. (Niluh, 2015)

Untuk menciptakan perusahaan yang efektif, komunikasi adalah sarana penting untuk mengkoordinasi dan integrasi dari beraneka ragam fungsi keorganisasian misalnya pernyataan tentang kebijaksanaan perusahaan, instruksi, memo resmi, laporan antara bagian administrasi dan pemasaran serta informasi pedoman kerja dan pengumuman perusahaan. Hal ini karena kemampuan komunikasi karyawan yang ditingkatkan akan memberikan dampak pada pesan-pesan yang dapat disampaikan secara jelas agar terhindar dari kesalahpahaman yang mungkin terjadi. Sebaliknya, bila kemampuan komunikasi karyawan sangat rendah dan berjalan tidak efektif akan dapat menimbulkan tekanan yang tidak perlu diantara para anggota perusahaan. Dengan meningkatnya kemampuan komunikasi karyawan baik horisantal maupun vertikal, terciptanya lingkungan kerja yang menyenangkan serta adanya perlakuan pimpinan yang baik dan menyenangkan yang dirasakan oleh karyawan, secara otomatis akan memotivasi karyawan untuk bekerja lebih giat. Kebaikan seperti ini akan mendukung citra perusahaan dalam masyarakat dan mengurangi keluar masuknya karyawan dalam perusahaan. (Ella, 2019). Komunikasi kerja sudah banyak di teliti oleh peneliti sebelumnya diantaranya adalah: (C.C. Widayati et al., 2020), (Christina Catur Widayati et al., 2020).

Tabel 1 : Penelitian Terlebih Dahulu

\begin{tabular}{|l|l|l|l|l|}
\hline No & \multicolumn{1}{|c|}{$\begin{array}{c}\text { Author } \\
\text { (Tahun) }\end{array}$} & \multicolumn{1}{|c|}{ Hasil Riset Terdahulu } & \multicolumn{1}{|c|}{$\begin{array}{c}\text { Persamaan dengan } \\
\text { artikel ini }\end{array}$} & \multicolumn{1}{c|}{$\begin{array}{c}\text { Perbedaan dengan } \\
\text { artikel ini }\end{array}$} \\
\hline 1 & $\begin{array}{l}\text { Meri Kurnia } \\
\text { Sari (2019) }\end{array}$ & $\begin{array}{l}\text { Kepemimpinan } \\
\text { Pendidikan }\end{array}$ & $\begin{array}{l}\text { Kualitas kerja dapat } \\
\text { berpengaruh terhadap } \\
\text { kepemimpinan }\end{array}$ & $\begin{array}{l}\text { Lebih berfokus menangani } \\
\text { permasalahan di dalam } \\
\text { ruang lingkup suatu } \\
\text { perusahaan }\end{array}$ \\
\hline 2 & $\begin{array}{l}\text { Arrafiqur } \\
(2017)\end{array}$ & $\begin{array}{l}\text { Kualitas kerja sekarang } \\
\text { dipandang sebagai } \\
\text { dimensi penting dari } \\
\text { kualitas hidup. Kualitas } \\
\text { kerja yang tinggi sangat } \\
\text { penting bagi organisasi } \\
\text { untuk menarik dan } \\
\text { mempertahankan } \\
\text { karyawan }\end{array}$ & $\begin{array}{l}\text { Kualitas kerja dilihat dari } \\
\text { cara pandang anggota } \\
\text { terhadap kualitas pekerjaan } \\
\text { yang dihasilkan juga } \\
\text { kesempurnaan dalam } \\
\text { menjalankan tugas } \\
\text { terhadap kemampuan } \\
\text { anggota. }\end{array}$ & $\begin{array}{l}\text { Terletak pada Kualitas } \\
\text { kerja merupakan topik } \\
\text { yang sangat penting dalam } \\
\text { manajemen sumber daya } \\
\text { manusia dalam } \\
\text { pembangunan organisasi }\end{array}$ \\
\hline
\end{tabular}




\begin{tabular}{|c|c|c|c|c|}
\hline 3. & $\begin{array}{l}\text { Astrianditya } \\
(2016)\end{array}$ & $\begin{array}{l}\text { perusahaan yang } \\
\text { berkualitas yaitu } \\
\text { perusahaan yang memiliki } \\
\text { kualitas hidup kerja yang } \\
\text { sangat baik, bisa } \\
\text { mensejahterakan } \\
\text { karyawan sehingga } \\
\text { menghasilkan karyawan } \\
\text { yang berkualitas dan } \\
\text { berkompetensi tinggi. }\end{array}$ & $\begin{array}{l}\text { Menguraikan Kualitas } \\
\text { kerja akan menimbulkan } \\
\text { kesan kepada pimpinan } \\
\text { organisasi yang nantinya } \\
\text { kesan tersebut akan } \\
\text { berdampak positif yang } \\
\text { bisa membuat kinerja } \\
\text { pemimpin meningkat dan } \\
\text { meningkatkan semangat } \\
\text { bagi pemimpin organisasi } \\
\text { untuk memimpin } \\
\text { kedepannya lagi. }\end{array}$ & $\begin{array}{l}\text { Perbedaanya yaitu Kinerja } \\
\text { karyawan menjadi bagian } \\
\text { terpenting untuk kemajuan } \\
\text { perusahaan di samping } \\
\text { strategi dan produk yang } \\
\text { inovatif. }\end{array}$ \\
\hline 4. & Reza (2019) & $\begin{array}{l}\text { Efektivitas kerja ialah } \\
\text { penyelesaian pekerjaan } \\
\text { tepat waktu yang telah } \\
\text { ditentukan. }\end{array}$ & $\begin{array}{l}\text { Kesamaannya yaitu efektif } \\
\text { jika suatu pekerjaan dapat } \\
\text { diselesaikan tepat waktu } \\
\text { sesuai dengan rencana } \\
\text { yang telah ditetapkan }\end{array}$ & $\begin{array}{l}\text { Menguraikan bahwa } \\
\text { variabel-variabel yang } \\
\text { sangat berpengaruh } \\
\text { terhadap efektivitas kerja } \\
\text { adalah komunikasi, } \\
\text { lingkungan kerja, } \\
\text { kepemimpinan, motivasi, } \\
\text { kebijakan dan praktek } \\
\text { manajemen }\end{array}$ \\
\hline 5. & Ella (2019) & $\begin{array}{l}\text { kemampuan komunikasi } \\
\text { karyawan yang } \\
\text { ditingkatkan akan } \\
\text { memberikan dampak } \\
\text { pada pesan-pesan yang } \\
\text { dapat disampaikan secara } \\
\text { jelas }\end{array}$ & $\begin{array}{l}\text { Persamaanya yaitu } \\
\text { komunikator dengan } \\
\text { bidang pengalaman } \\
\text { komunikan, akan semakin } \\
\text { efektif pesan yang } \\
\text { dikomunikasikan. }\end{array}$ & $\begin{array}{l}\text { berfokus sarana penting } \\
\text { untuk mengkoordinasi } \\
\text { dan integrasi dari } \\
\text { beraneka ragam fungsi } \\
\text { keorganisasian }\end{array}$ \\
\hline 6. & Niluh (2015) & $\begin{array}{l}\text { Komunikasi dalam } \\
\text { perusahaan bisa dikatakan } \\
\text { penentu keberhasilan } \\
\text { dalam } \\
\text { Pencapaian tujuan }\end{array}$ & $\begin{array}{l}\text { Suatu proses berinteraksi } \\
\text { atau terjadinya transaksi } \\
\text { dengan maksud dimana } \\
\text { komponen-komponennya } \\
\text { saling terkait }\end{array}$ & $\begin{array}{l}\text { Befokus pada proses - } \\
\text { proses komunikasi }\end{array}$ \\
\hline
\end{tabular}

\section{METODE PENULISAN}

Metode penulisan artikel ilmiah ini adalah dengan metode kualitatif dan kajian pustaka (Library Research). Mengkaji teori dan hubungan atau pengaruh antar variabel dari buku-buku dan jurnal baik secara off line di perpustakaan dan secara online yang bersumber dari Mendeley, Scholar Google dan media online lainnya. Dalam penelitian kualitatif, kajian pustaka harus digunakan secara konsisten dengan asumsi-asumsi metodologis. Artinya harus digunakan secara induktif sehingga tidak mengarahkan pertanyaan-pertanyaan yang diajukan oleh peneliti. Salah satu alasan utama untuk melakukan penelitian kualitatif yaitu bahwa penelitian tersebut bersifat eksploratif, (Ali \& Limakrisna, 2013).

\section{HASIL DAN PEMBAHASAN}

Pengaruh Kualitas Kerja terhadap Kepemimpinan 
Kualitas kerja adalah nilai hasil kerja dari anggota organisasi yang dilakukan melebihi standar kinerja yang berarti menyesuaikan beberapa cara yang ideal dari penampilan aktivitas ataupun memenuhi tujuan yang menjadi standar dalam organisasi. Kualitas kerja dilihat dari cara pandang anggota terhadap kualitas pekerjaan yang dihasilkan juga kesempurnaan dalam menjalankan tugas terhadap kemampuan anggota. Menurut Robbins (1996) kinerja bisa di katakan sebagai fungsi interaksi antara kemampuan atau ability, motivasi atau dan kesempatan atau yang berarti kinerja merupakan fungsi dari kemampuan, motivasi, dan kesempatan. Konsep performa kerja dipandang sebagai hal yang relatif, bukan berarti selalu mengandung arti yang baik, ataupun positif. Performa dapat mengartikan sifat yang dimiliki oleh suatu organisasi yang ditunjukkan kepada orang - orang atas kelebihan yang dimiliki organisasi tersebut. Perkembangan kualitas kerja dalam organisasi merupakan hal penting yang perlu diperhatikan. Kualitas kerja terkait diperlukan untuk mempengaruhi operasi pemimpin organisasi pada personel operasi. Berkembangnya kualitas kerja akan menimbulkan kesan kepada pimpinan organisasi yang mana nantinya kesan tersebut akan berdampak positif yang bisa membuat kinerja pemimpin meningkat dan meningkatkan semangat bagi pemimpin organisasi untuk memimpin kedepannya lagi.

\section{Pengaruh Efektivitas kerja terhadap Kepemimpinan}

Menurut Richard M. Steers (1980 : 1), efektivitas yang berasal dari kata efektif, yaitu suatu pekerjaan bisa di sebut efektif jika suatu pekerjaan dapat menghasilkan satu unit keluaran (output). Pekerjaan bisa dikatakan efektif jika suatu pekerjaan dapat diselesaikan tepat waktun sesuai dengan rencana yang telah ditetapkan. Efektivitas kerja merupakan kondisi suasana kerja yang berada ditingkat dirasa nyaman, tentram dan bebas dalam melakukan pekerjan tanpa adanya rasa takut untuk menimbulkan suasana yang kondusif apabila terciptanya hubungan antara manusia berkembang dengan sangat baik. keadaan suasana kerja yang nyaman dan tenang untuk memungkinkan kinerja dari pemimpin meningkat.

Berikut beberapa faktor yang mempengaruhi efektivitas kerja, seperti yang disebutkan oleh Richard M. Steers (1980:9), yaitu:

a) Karakteristik Organisasi

Karakteristik organisasi ini terdiri dari struktur dan teknologi organisasi yang dapat mempengaruhi segi-segi tertentu dari efektivitas dengan berbagai cara. Yang dimaksud struktur yaitu hubungan yang relatif tepat sifatnya, seperti dijumpai dalam organisasi, sehubungan dengan susunan sumber daya manusia struktur meliputi bagaimana cara organisasi membentuk orang-orangnya dalam menyelesaikan pekerjaan, sedangkan yang dimaksud tehnologi adalah mekanisme suatu organisasi umtuk mengubah masukan mentah menjadi keluaran.

b) Karakteristik Lingkungan

Lingkungan luar dan dalam juga telah disebutkan berpengaruh atas efektivitas, keberhasilan hubungan organisasi lingkungan tampaknya amat tergantung pada tingkat variabel kunci yaitu tingkat keterdugaan keadaan lingkungan, ketepatan persepsi atas 
keadaan lingkungan,tingkat rasionalisme organisasi. Ketiga faktor ini mempengaruhi ketepatan tanggapan organisasi terhadap perubahan lingkungan.

c) Karakteristik Pekerja

Pada kenyataannya para anggota organisasi adalah faktor pengaruh terpenting karena perilaku merekalah yang dalam jangka panjang akan memperlancar atau merintangi tercapainya tujuan organisasi. Pekerja adalah sumber daya yang langsung berhubungan dengan pengelolaan semua sumber daya yang ada di dalam organisasi, oleh karena itu perilaku pekerja sangat berpengaruh terhadap pencapaian tujuan suatu organisasi.

Pekerja adalah modal utama di dalam suatu organisasi yang akan berpengaruh besar terhadap efektivitas, karena walaupun tehnologi yang digunakan merupakan teknologi yang canggih didukung juga oleh struktur yang baik, namun tanpa adanya pekerja maka semua itu tidak ada gunanya.

d) Karakteristik Kebijaksanaan dan Praktek Manajemen

Dengan makin rumit nya suatu proses teknologi dan perkembangan lingkungan maka peranan manajemen dalam mengkoordinasi orang dan proses demi keberhasilan organisasi semakin sulit.

\section{Pengaruh Komunikasi kerja terhadap Kepemimpinan}

Menurut Widjaja (2008: 1), Komunikasi merupakan hubungan kontak antar dan antara manusia baik individu maupun kelompok. Dalam kehidupan sehari-hari disadari atau tidak komunikasi yaitu bagian dari kehidupan manusia itu sendiri. Manusia mulai pertama dilahirkan sudah berkomunikasi dengan lingkungannya. Proses komunikasi adalah suatu proses berinteraksi atau terjadinya transaksi dengan maksud dimana komponen-komponennya saling terkait dan para komunikator beraksi dan bereaksi.

Proses komunikasi terbagi menjadi dua tahap yaitu :

a) Proses Komunikasi Secara Primer

Proses komunikasi secara primer adalah proses penyampaian pikiran dan atau perasaan seseorang kepada orang lain dengan menggunakan lambang (symbol) sebagai media. Lambang untuk media primer dalam proses komunikasi merupakan bahasa, kial, isyarat, gambar, warna, dan lain sebagainya yang secara langsung mampu "menerjemahkan" pikiran dan atau perasaan komunikator kepada komunikan.

b) Proses Komunikasi Secara Sekunder

Proses komunikasi secara sekunder yaitu proses penyampaian pesan oleh seseorang kepada orang lain dengan menggunakan alat atau sarana sebagai media kedua setelah memakai lambang sebagai media pertama. Seorang komunikator menggunakan media kedua dalam melancarkan komunikasinya karena komunikan sebagai sasarannya berada di tempat yang relatif jauh atau jumlahnya banyak. Surat, telepon, teleks, surat kabar, majalah, radio, televisi, film, dan banyak lagi adalah media kedua yang sering digunakan dalam komunikasi. Effendy ( 2007 : 11). Proses komunikasi memiliki tujuh unsur, diantaranya sumber, pesan, media, penerima, pengaruh, tanggapan balik, lingkungan. Setiap unsur memiliki peranan yang sangat penting dalam membangun proses komunikasi. Bahkan ketujuh unsur ini saling bergantung satu sama lainnya. 
Artinya, tanpa ke ikutsertaan satu unsur akan memberi pengaruh pada jalannya komunikasi, Cangara (2010 : 28). Agar komunikasi efektif, proses penyandian oleh komunikator harus bertautan dengan proses pengawasan sandian oleh komunikan. Effendy (2007 : 19) melihat pesan sebagai tanda esensial yang harus dikenal oleh komunikan. Semakin tumpang tindih bidang pengalaman (field of experience) komunikator dengan bidang pengalaman komunikan, akan semakin efektif pesan yang dikomunikasikan.

\section{Conceptual Framework}

Berdasarkan perumusan masalah yang dibahas artikel ini dan kajian studi literatur review baik dari buku dan artikel yang bersangkutan, dapat diperolah rangka artikel seperti dibawah ini.

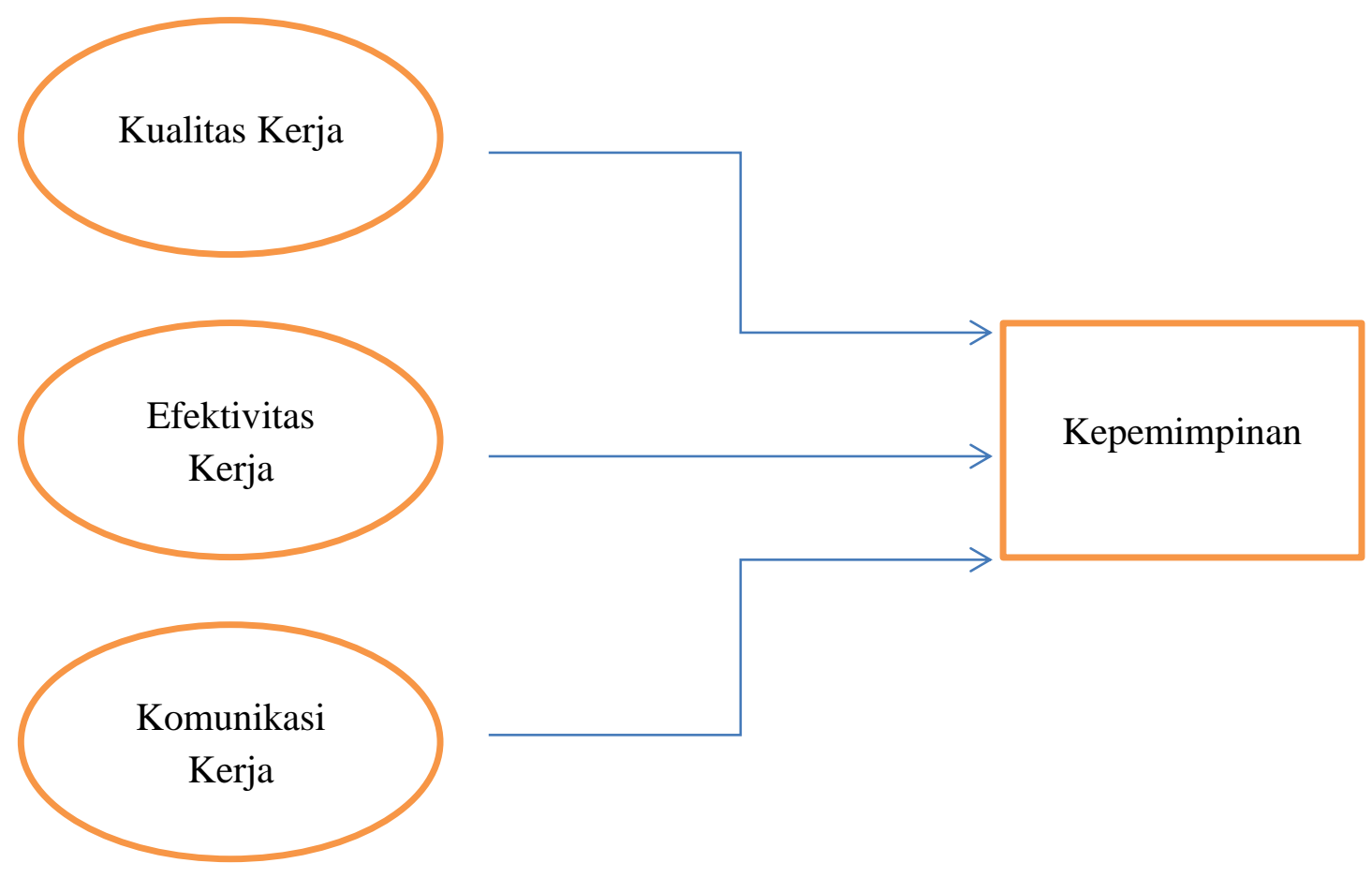

Figure 1 : Conceptual Framework

Berdasarkan gambar conceptual framework di atas, maka: Kualaitas kerja (X1), Efektivitas kerja (X2) dan komunikasi kerja (X3) berpengaruh terhadap Kepemimpinan (Y).

Selain dari tiga variabel exogen ini yang mempengaruhi Kepemimpinan (Y), masih banyak variabel lain yang mempengaruhinya diantaranya adalah:

1) Linkungan kerja (X4): (Purba et al., 2017), (Sardjijo \& Ali, 2017);

2) Motivasi kerja (X5): (Riyanto et al., 2017), (Bastari et al., 2020), (Prayetno \& Ali, 2017), (Rivai et al., 2017), (Chauhan et al., 2019); dan

3) Budaya kerja (X6): (Harini et al., 2020), (Elmi et al., 2016). 


\section{KESIMPULAN DAN SARAN \\ Kesimpulan}

Berdasarkan teori, artikel yang relevan dan pembahasan maka dapat di rumuskan hipotesis untuk riset selanjutnya:

1. Kualitas Kerja berpengaruh terhadap kepemimpinan.

2. Efektivitas Kerja berpengaruh terhadap kepemimpinan.

3. Komunikasi Kerja berpengaruh terhadap kepemimpinan.

\section{Saran}

Berdasarkan kesimpulan di atas, maka saran dari artikel ini adalah bahwa masih banyak faktor-faktor yang mempengaruhi kepemimpinan selain Kualitas kerja, Efektivitas karyawan dalam bekerja dan Komunikasi karyawan dalam bekerja karena seorang pemimpin itu memegang kendali penuh dalam suatu perusahaan yang dia pimpin.

\section{DAFTAR RUJUKAN}

Agussalim, M., Ayu Rezkiana Putri, M., \& Ali, H. (2016). Analysis work discipline and work spirit toward performance of employees (case study tax office Pratama two Padang). International Journal of Economic Research.

Ali, H., Mukhtar, \& Sofwan. (2016). Work ethos and effectiveness of management transformative leadership boarding school in the Jambi Province. International Journal of Applied Business and Economic Research.

Ansori, A., \& Ali, H. (2017). Analisis Pengaruh Kompetensi Dan Promosi Terhadap Kinerja Pegawai Negeri Sipil Pada Sekretariat Daerah Kabupaten Bungo. Jurnal Ilmiah Universitas Batanghari Jambi. https://doi.org/10.33087/jiubj.v15i1.198

Anwar, K., Muspawi, M., Sakdiyah, S. I., \& Ali, H. (2020). The effect of principal's leadership style on teachers' discipline. Talent Development and Excellence.

Arrafiqur, R. 2017. Kualitas Kehidupan Kerja; Suatu Tinjauan Literatur

Dan Pandangan Dalam Konsep Islam.

Astrianditya. 2016. Pengaruh Kualitas Kehidupan Kerja Dan Kepuasan Kerja Terhadap

Kinerja Karyawan

Burhanudin. 2018. Kepemimpinan Dalam Budaya Organisasi

Bastari, A., -, H., \& Ali, H. (2020). DETERMINANT SERVICE PERFORMANCE THROUGH MOTIVATION ANALYSIS AND TRANSFORMATIONAL LEADERSHIP. International Journal of Psychosocial Rehabilitation. https://doi.org/10.37200/ijpr/v24i4/pr201108

Chauhan, R., Ali, H., \& Munawar, N. A. (2019). BUILDING PERFORMANCE SERVICE THROUGH TRANSFORMATIONAL LEADERSHIP ANALYSIS, WORK STRESS AND WORK MOTIVATION (EMPIRICAL CASE STUDY IN STATIONERY DISTRIBUTOR COMPANIES). Dinasti International Journal of Education Management And Social Science. https://doi.org/10.31933/dijemss.v1i1.42

Djoko Setyo Widodo, P. Eddy Sanusi Silitonga, \& H. A. (2017). Organizational Performance: Analysis of Transformational Leadership Style and Organizational Learning. Saudi Journal of Humanities and Social Sciences. 
https://doi.org/10.21276/sjhss.2017.2.3.9

Elmi, F., \& Ali, H. (2017). The effect of incentive, training, and career development on productivity of PT. Pelita Cengkareng paper's workers. International Journal of Applied Business and Economic Research.

Elmi, F., Setyadi, A., Regiana, L., \& Ali, H. (2016). Effect of leadership style, organizational culture and emotional intelligence to learning organization: On the Human Resources Development Agency of Law and Human Rights, Ministry of Law and Human Rights. International Journal of Economic Research.

Ella, A. 2019. Pengaruh Kedisiplinan Dan Komunikasi Kerja Terhadap Kinerja Karyawan

Harini, S., Hamidah, Luddin, M. R., \& Ali, H. (2020). Analysis supply chain management factors of lecturer's turnover phenomenon. International Journal of Supply Chain Management.

Hasan, B. 2017. Peningkatan Kompetensi Guru Melalui Sistem Kepemimpinan Karyawan

Limakrisna, N., Noor, Z. Z., \& Ali, H. (2016). Model of employee performance: The empirical study at civil servants in government of west java province. International Journal of Economic Research.

Masydzulhak, P. D., Ali, P. D. H., \& Anggraeni, L. D. (2016). The Influence of work Motivationand Job Satisfaction on Employee Performance and Organizational Commitment Satisfaction as an Intervening Variable in PT. Asian Isuzu Casting Center. In Journal of Research in Business and Management.

Mardani, E. 2013. Peranan Komunikasi Internal Di Lingkungan Kerja

Meri Kurnia, S. 2019 Kepemimpinan Pendidikan

Niluh, G. 2015. Pengaruh Motivasi Kerja, Komunikasi Dan Stres Kerja

Nur, K. 2012. Hubungan Manajemen Waktu Dengan Efektivitas Kerja

Prayetno, S., \& Ali, H. (2017). Analysis of advocates organizational commitment and advocates work motivation to advocates performance and its impact on performance advocates office. International Journal of Economic Research.

Prayetno, S., \& Ali, H. (2020). The influence of work motivation, entrepreneurship knowledge and advocate independence on advocate performance. International Journal of Innovation, Creativity and Change.

Purba, C. B., Arzio, \& Ali, H. (2017). The influence of compensation, working environment and organization culture on working productivity of BPJS (workers social security agency) employment staff in Rawamangun Branch. Man in India.

Rivai, A., Suharto, \& Ali, H. (2017). Organizational performance analysis: Loyalty predictors are mediated by work motivation at urban village in Bekasi City. International Journal of Economic Research.

Riyanto, S., Sutrisno, A., \& Ali, H. (2017). International Review of Management and Marketing The Impact of Working Motivation and Working Environment on Employees Performance in Indonesia Stock Exchange. International Review of Management and Marketing.

Reza, N. 2019. Kepemimpinan, Komunikasi Dan Efektivitas Kerja Pegawai Pemerintah Kota Lhokseumawe Terhadap Kepuasan Kerja Karyawan

Sardjijo, S., \& Ali, H. (2017). Integrating Character Building into Mathematics and Science 
Courses in Elementary School. International Journal of Environmental and Science Education. https://doi.org/10.1007/s10648-016-9383-1

Silitonga, P. E. S., Widodo, D. S., \& Ali, H. (2017). Analysis of the effect of organizational commitment on organizational performance in mediation of job satisfaction (Study on Bekasi City Government). International Journal of Economic Research.

Widayati, C.C., Ali, H., Permana, D., \& Nugroho, A. (2020). The role of destination image on visiting decisions through word of mouth in urban tourism in Yogyakarta. International Journal of Innovation, Creativity and Change, 12(3).

Widayati, Christina Catur, Ali, H., Permana, D., \& Nugroho, A. (2020). The role of destination image on visiting decisions through word of mouth in urban tourism in Yogyakarta. International Journal of Innovation, Creativity and Change. 